\title{
Government Aid for Start-ups
}

Mrs.Dhanalakshmi K, Assistant Professor, Acharya Institute of Graduate Studies, Bangalore. dhanusamuel@gmail.com

\begin{abstract}
Entrepreneurship is the dynamic process of creating incremental wealth. It was only from the year 2000 and the launch of companies like FlipKart and one97 communications, which runs "Paytm", that start-ups, termed as a career and paved a way for life and legitmacy. Thus, this paper is focused on how government is helping to grow startups. It gives brief outline on the schemes, policies and opinions performed by the State and Central Government with hand in hand to increase/boost up the economy of the nation. It has also emphasized to know about the success and failure rates of the plans/steps taken by the Government.
\end{abstract}

The plan of startups was mainly to increase employment rates and this is only possible by initiative of Government at a larger scale. In the paper, finance, innovation, marketing, Infrastructure, technology are the areas considered for knowing better about Government aid for start-ups in the emerging economy.

Keywords: Startups, Government Support, Schemes, Awareness and Acceptance

\section{GOVERNMENT AID FOR START-UPS}

\section{Introduction}

To empower the Indian Startups, Indian Government is helping the public either in forms of funding, tax rebates, mentorship or guiding platforms. But as we go on date only 1,333 applicants have been recognized as start-ups by the DIPP, while only 39 Indian start-ups have been approved for availing tax benefits (IMB, 2nd week December, 2018). The formation of 1000 tinkering labs at school levels' gives an appeal to local MPs to create an increase wave of positivity on start-ups. The Indian Government's recent attempt to build exchange programmes with foreign start-ups in countries like Germany, SAARC countries will further open doors of the stakeholders in the start-up economy.

There are 50+ startup schemes available to interested individuals and entities or startups that they can benefit from. Start ups having a product or service in an idea stage, a pilot model stage or running full-scale businesses. Academics (especially STEM fields) too have been given due consideration. But, the fact remains that stakeholders need to be made aware of these programmes and initiatives and the bureaucratic red tape involved in getting these benefits need to be reduced too. The present Indian Government has less than one year before a new regime comes to power. It remains to be seen what benefits, startup schemes and startup-centric initiatives will it undertake in order to realize the vision of Startup India Stand Up India.

In the present scenario, startups initiatives are taken by most of the developing countries and thus create positive growth in society, economy and technology. It has an impact on national income and knowledge economy. India is in $3^{\text {rd }}$ position in world for startups; recently Government of India has taken the initiative for startups and has given relaxation to public for new startups. By ease of policies of government many new startups have started and many of them are successful. 


\section{Entrepreneurship and Startups}

In India, unemployment rates are high so in this context Government started startups to create small business entity with some novel idea , with some innovation, many new business will create competition in market.

A key concept of the knowledge economy is that knowledge and education often referred to as "human capital" can be treated as

- A business product, as educational and innovative intellectual products and services can be exported for a high value return.

- A productive asset.

Government support in knowledge support:

The Ministry of Human Resource Development and the Department of Science and Technology have agreed to partner in an initiative to set up over 75 such startup support hubs in the National Institutes of Technology (NITs), the Indian Institutes of Information Technology (IIITs), the Indian Institutes of Science Education and Research (IISERs) and National Institutes of Pharmaceutical Education and Research (NIPERs).

Government has the major role in Startup India and is focused on to restrict role of States in policy domain and to get rid of "License Raj" and problems like land permissions, foreign investment proposal, environmental clearances.

- This policy is launched by Ministry of Commerce and Industry Government of India.

- A startup is an entity that is headquartered in India which was opened less than five years ago and has an annual turnover of less than Rs. 25 crore.

- MUDRA Bank, a new institution has been set up for development and refinancing activities relating to micro units with a refinance Fund of Rs. 200 billion.

Startups provided a platform to bring together all stakeholders, stimulate dialogue on key challenges that the Indian innovation ecosystem currently faces, and provide the solutions to address them. The process is ongoing and proposes to provide fruitful culture of innovation in the country as an integral part of Startup India.

\section{Research Methodology}

The initiatives like Start Up India, Digital India, Make In India are really successful and are helping to solve the problems like unemployment, poverty, standard of living, etc., and increasing the national income and gross domestic product. Hence, this paper is an attempt being made to focus on how start ups are supported by the Government and are they really successful. The research design followed to this study is a Descriptive study as it only studies on the attitudes / behaviour of start-ups where the Government has aided them to start their business or not.

\section{Objectives of the Study}

- To study few startups schemes available for the entrepreneurs.

- To know- how Government is supporting startups.

- To study onfew start-ups entrepreneurs opinion on Government aid to start-up.

\section{Research Design}

This study is a Descriptive and Analytical research. The study describes on the variables of the start-up schemes available as well as how Government is aiding for the start-ups. However, the study has also analysed on how government supports startups as a part of entrepreneurship for job creation and has aided for start-ups on a survey basis.

\section{Sampling Method and Technique}

The sampling method followed for conducting this study is a probability sampling method, under which the study was aimed to follow the random sampling method, as the start-ups in and around the area were few and had to pick based on the respondents response given. 


\section{Entrepreneurship and Startups}

The sample size is 22 start-ups, located in and around the Acharya Institute of Graduate Studies, Soladevanahalli, Bangalore.

\section{Data collection}

\section{a) Primary data}

A well framed questionnaire was designed and the data was collected in and around surrounding areas of Acharya Institute of Graduate Studies, Soldevanahalli, Hessarghatta main road. The questionnaire is enclosed in the Annexure.

b) Secondary data

Information was also collected through websites, articles in the journals, news papers, magazines, etc.

\section{Research Instruments}

The study is analysed using simple percentage method and presented in a graphical manner. The test is also conducted using chi-square test and correlation method.

\section{Hypothesis}

H0:Startups are not supported by the Government

H1:Startups are supported by the Government

\section{Limitations of the study}

- There was both Time constraint and Financial constraint.

- Data used is purely based on the accuracy of the information provided by the respondents.

\section{Data Analysis}

\section{Initiatives taken by the Government}

- Single Window Clearance even with the help of a mobile application.

- 10,000 crores of rupees assigned.

- $80 \%$ reduction in patent registration fee.

- Modified and friendlier Bankruptcy Code to ensure 90-day exit window.
- Freedom from inspections for 3 years.

- Freedom from Capital Gain Tax for 3 years.

- Freedom from tax in profits for 3 years.

- Self-certification compliance.

- Innovation hub under Atal Innovation Mission.

- Starting with 5 lakh schools to target 10 lakh children for innovation programmes.

- Encourage entrepreneurship.

- Stand India across the world as a start-up hub.

Initiatives in infrastructure sector from government to raise startups

- India's Time tested institution offers foreign investors a transparent environment that guarantees the security of their long term investments.

- The national highways act has been modified to the reduction of damages on national motor way, bridges and tunnels. This will help in transportation on goods from one place to other.

- According to the 12th 5year plan an increasing trend for investment in infrastructure can be seen as a percentage of GDP to $9 \%$ by the end of this plan, also to increase the gross irrigated area from 90 million hectares to 103 million hectares by the end of this plan.

- Service delivery to provide access to banking service to $90 \%$ Indian households by the end of the plan.

\section{Government Support in terms of finance to startups}

- To gather finance, India has been showing positive response to ROW. Different business councils of USA, Middle East, China, European countries has invested in India supplying financial help to startups. 


\section{Entrepreneurship and Startups}

- On Jan 2017 Alternative Investment Summit India was conducted to provide an ideal platform for meeting potential investors develop quality business development opportunities.

- As mentioned government has also came with lots of financial and legal related points to support startups.

Things which are done in marketing as recent trends in marketing and with relation to technology:

- Startups have brought a huge increase in Ebusiness, E-business is very friendly to both customers and producers to do business and gather information about everything.

- Tele marketing have increased considerably as customer and business want easy and fast process of goods at door steps. New startups product base business is going for this type of marketing.

- M-business helps to do shopping by smart pone now days mobile apps are helping consumer to do shopping and get services. Most of the startups are starting their business by mobiles apps example - UBER, OYO, FLIPKART etc.

- Startup business is also involving in relationship marketing. This is to focus and strengthen the relation between producer and customer.

Work of government in providing information related to startups schemes

- Many summit were done by Government for startups and related objectives of it.

- India hosted US government Global Entrepreneurship Summit in 2017.

- Vibrant Gujarat global summit.

- Momentum Jharkhand Investors, etc.,
Few examples of start-ups in India are :

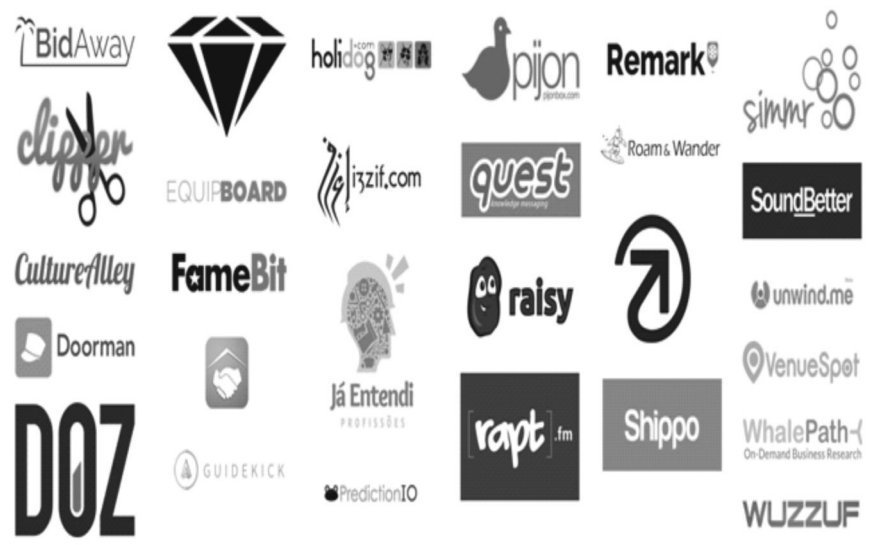

Table1 :Showing the awareness of start-up schemes in India

\begin{tabular}{|l|c|c|}
\hline \multirow{2}{*}{ Opinion of entities } & \multicolumn{2}{|c|}{ Number of respondents (\%) } \\
\cline { 2 - 3 } & Yes & No \\
\hline Aware & 59 & 41 \\
\hline
\end{tabular}

Inference :About 59\%were aware about the schemes that were up for the startups out of them $41 \%$ were unaware, which implies Government has to create the awareness campaign a lot on the start-ups schemes.

Table2 : Showing the type and longevity and Performance of their start-ups

\begin{tabular}{|l|l|l|l|}
\hline Type & $\begin{array}{l}\text { No. of } \\
\text { respon } \\
\text { dents }\end{array}$ & $\begin{array}{l}\text { Longevity } \\
\text { (years), } \\
\text { given in } \\
\text { range }\end{array}$ & $\begin{array}{l}\text { Perfor } \\
\text { mance } \\
\text { (Range) }\end{array}$ \\
\hline Fashion and Design & 5 & $1-5$ & medium \\
\hline $\begin{array}{l}\text { Food Restaurants } \\
\text { including Bakery }\end{array}$ & 3 & $1-5$ & medium \\
\hline Electronic Show rooms & 5 & $0-10$ & medium \\
\hline Jeweler shops & 1 & $5-10$ & low \\
\hline Provision stores & 4 & $15-$-above & medium \\
\hline Fancy stores / Articrafts & 2 & $0-10$ & medium \\
\hline Housing & 1 & $0-5$ & medium \\
\hline Hyper markets & 1 & $5-10$ & medium \\
\hline
\end{tabular}

Inference :36\% of the entrepreneurs were new in their field (about 1-5 yrs) and performance of entrepreneurs are moderate in their business. 


\section{Entrepreneurship and Startups}

Table3: Showing whether Government helped them to start their business start-ups

\begin{tabular}{|l|l|l|}
\hline Type & \multicolumn{2}{|l|}{$\begin{array}{l}\text { Number of } \\
\text { respondents }\end{array}$} \\
\hline & $\begin{array}{l}\text { Financial } \\
\text { support }\end{array}$ & $\begin{array}{l}\text { Non- } \\
\text { financial } \\
\text { support }\end{array}$ \\
\hline Fashion and Design & 2 & 1 \\
\hline Food Restaurants including Bakery & 0 & 1 \\
\hline Electronic Show rooms & 1 & 1 \\
\hline Jewellary shops & 0 & 0 \\
\hline Provision stores & 0 & 0 \\
\hline Fancy stores / Articrafts & 0 & 0 \\
\hline Housing & 0 & 0 \\
\hline Hyper markets & 0 & 0 \\
\hline
\end{tabular}

Inference : $82 \%$ of the entrepreneurs were selfdependent and did not seek any help from the Government in setting up their business, which implies the respondents were not eager to take the help of Government to start the business.

Table4 : Showing that Government is helping the start ups

\begin{tabular}{|l|c|c|c|c|c|}
\hline Type & \multicolumn{5}{|c|}{ Number of respondents } \\
\hline & $\begin{array}{c}\text { Strongly } \\
\text { agree }\end{array}$ & Agree & $\begin{array}{c}\text { Neu } \\
\text { tral }\end{array}$ & $\begin{array}{c}\text { Disa } \\
\text { gree }\end{array}$ & $\begin{array}{c}\text { Strongly } \\
\text { Disagree }\end{array}$ \\
\hline Fashion and Design & 0 & 3 & 0 & 2 & 0 \\
\hline $\begin{array}{l}\text { Food Restaurants } \\
\text { including Bakery }\end{array}$ & 1 & 2 & 0 & 0 & 0 \\
\hline Electronic Show rooms & 2 & 2 & 0 & 1 & 0 \\
\hline Jewellary shops & 0 & 1 & 0 & 0 & 0 \\
\hline Provision stores & 0 & 3 & 1 & 0 & 0 \\
\hline Fancy stores / Articrafts & 0 & 1 & 1 & 0 & 0 \\
\hline Housing & 0 & 1 & 0 & 0 & 0 \\
\hline Hyper markets & 0 & 0 & 0 & 1 & 0 \\
\hline
\end{tabular}

Inference : $73 \%$ of them agree that the Government was up to the mark in helping startups.

\section{$M_{\text {ABBS }}$}

Table5 : Showing that GST bill plan will help to grow start ups

\begin{tabular}{|l|c|}
\hline Type & Number of respondents \\
\hline $0-40 \%$ & 6 \\
\hline $40-80 \%$ & 14 \\
\hline $80-100 \%$ & 2 \\
\hline
\end{tabular}

Inference : 64\%of them agreed that the GST bill plan of India was seen as a success if implemented. Success rates are $40-80 \%, 27 \%$ for $0-40 \%$ and $9 \%$ for $80-100 \%$, respectively.

Table6 : Showing that demonetization has affected the start ups

\begin{tabular}{|l|c|}
\hline Type & Number of respondents \\
\hline $0-30 \%$ & 8 \\
\hline $30-70 \%$ & 12 \\
\hline $70-100 \%$ & 2 \\
\hline
\end{tabular}

Inference : 55\%of the entrepreneurs felt their business fluctuated from $30-70 \%$ due to demonetization $36 \%$ for $0-30 \%$ and $9 \%$ for $80-100 \%$, which implied that there was a lot of impact on startups.

Table 7 : Showing that technology has played a major role in the success of business

\begin{tabular}{|l|c|}
\hline Type & Number of respondents \\
\hline Digital payments & 16 \\
\hline Online orders & 7 \\
\hline Increasing productivity & 3 \\
\hline M-business & 1 \\
\hline Others & 6 \\
\hline
\end{tabular}

Inference : 95\% agreed to the point that technology played a important role in business. $91 \%$ of the entrepreneurs were where using digital way of transaction through the support of Government.

Table8: Showing digitalization has helped their business

\begin{tabular}{|l|c|}
\hline Particulars & Number of respondents \\
\hline Yes & 21 \\
\hline No & 1 \\
\hline
\end{tabular}




\section{Entrepreneurship and Startups}

Inference : 95\% of the respondents have expressed that digitalization has helped their business a lot.

Table9: Showing colleges can bring out more startups

\begin{tabular}{|l|c|}
\hline Particulars & Numberof respondents \\
\hline Yes & 12 \\
\hline No & 10 \\
\hline
\end{tabular}

Inference : $54.5 \%$ of the respondents have conveyed that colleges can aid to bring out more startups through educating them or associating with Government agencies.

Table10 : Showing startups does e-business

\begin{tabular}{|l|c|}
\hline Particulars & Numberof respondents \\
\hline Yes & 17 \\
\hline No & 5 \\
\hline
\end{tabular}

$77 \%$ agrees that e business is supported by startups.

\section{Hypothesis testing}

HO : Start-ups are not supported by the Government

H1 : Start-ups are supported by the Government

\begin{tabular}{|l|c|c|c|}
\hline $\mathrm{O} 1$ & $\mathrm{E}$ & $\mathrm{O}-\mathrm{E}$ & $(\mathrm{O}-\mathrm{E})^{*}(\mathrm{O}-\mathrm{E})$ \\
\hline 14 & 22 & 8 & 64 \\
\hline 4 & 22 & 18 & 324 \\
\hline 4 & 22 & 18 & 324 \\
\hline & & TOTAL & 712 \\
\hline
\end{tabular}

$\ell * \ell=\sum(\mathrm{O} 1-\mathrm{E} 1) *(\mathrm{O} 1-\mathrm{E} 1) / \mathrm{E} 1$

$=712 / 22$

$=32.36$

$\mathrm{CV}<\mathrm{TV}=$ Accept Ho

$\mathrm{CV}>\mathrm{TV}=$ Reject Ho

\section{$32.36>5.991$ Reject Ho}

Thus, we can infer that at $5 \%$ significance level, Startups are supported by the Government.

\begin{tabular}{|l|c|}
\hline Particulars & No. of respondents \\
\hline $\begin{array}{l}\text { Longevity (years), } \\
\text { given in range }\end{array}$ & -0.365850258 \\
\hline
\end{tabular}

The above table also depicts that there is no positive co-relation on the number of respondents doing their business from the last 30 years, which infers that doing the business for long time is not only the factor to decide on the success rate of the business.

\section{Summary of Findings}

- Unawareness: As per our survey we saw that most of the people were unaware about innovative plan of government to help startups. We also found that people has lack of support as they are not well oriented about startups.

- Lack of proper education: Government has brought lot of guidance policies related to success of startups but still education remains a challenge. Most of the people in India are uneducated they still lack in technology so, providing knowledge is a very challenging task. As per our survey some people told that college may not help in startups and unawareness is a factor so proper education is not there.

- Not in support of government by opposition: Many parties who are in opposition of government will tell negative about the government. That will create issue in plans of government.

- Problems of ventures: Lot of problems are created in ventures in distribution, difference of thinking, style of working differs etc.,

- Not thinking out of the box - most of the startups are coping each other, no new ideas are created because of it, and only increase in competition is there.

- Various facts about the Government involvement in startups that $36 \%$ of the entrepreneurs were new in their field (about 1$5 \mathrm{yrs})$ and performance of entrepreneur's medium in their business. About 59\% were aware about the schemes that were up for the startups out of them $41 \%$ were unaware. $55 \%$ of the entrepreneurs felt their business fluctuated from $30-70 \%$ due to demonetization $36 \%$ for $0-30 \%$ and $9 \%$ for $80-100 \%$. 95\% agreed 


\section{Entrepreneurship and Startups}

to the point that technology played a important role in business. $91 \%$ of the entrepreneurs were where using digital way of transaction in support of Government. 64\% of them agreed that the GST bill plan of India was seen as a success if implemented. Success rates are $40-80 \%, 27 \%$ for $0-40 \%$ and $9 \%$ for $80-100 \%$, respectively.

\section{Suggestions}

- The people have to work hand-in -hand with government to bring the out of the plans. If only the people could support only then, will we be able to see some positive outcome.

- More awareness programmers should be conducted for the public college should support in providing a basic knowledge about the things like startups.

- These schemes were introduced in order to have self employment in some kind of innovative business.

- Much involvement of technology should be encouraged i.e. digital payment, online order, $\mathrm{m}$ business.

- The people should have a positive perception of the government.

\section{Conclusion}

As per analysis and research, it can be concluded that Government is doing good job in the field of startups. The paper gives a brief about the success and failure of the Government.Startups is itself means self employment so that the people can be sure about their scale and way of earning which will lead to decrease in unemployment and under employment rates.

\section{References}

\section{Websites}

1. http://timesofindia.indiatimes.com/trendtracking/India-to-host-US-govts-GlobalEntrepreneurship-Summit-in-2017/articleshow/ 52897533.cms

2. www.wikipedia.orghttps://en.wikipedia.org/ wiki/Startup_company
3. www.entrepreneure.com

4. www.startupindia.gov.in

\section{Magazines}

1. The entrepreneur magazine.

\section{ANNEXURE}

Ms. Dhanalakshmi K, Research Scholar, is conducting on research on Entrepreneurship and the knowledge economy. I am looking forward for your valuable information. The information taken will only be used for reference purpose of our research. This confidential information shall not be misused anywhere without your knowledge.

\section{PART A}

Name Age

Address

Name of the firm

E- Mail id

Phone no

\section{PART B}

Q.1) Do you know about, start up schemes of the government?

Yes or No

If yes specify-
MUDRA Bank
Digital/ technology sector
IMADE app
Others

Q.2) How long had you started your business?
1-5 years
5-10years
10-15years
15years and above

Q3.) Is there a role of government to start your business?

Yes or No

If yes specify......Financial support and Non financial Support

\section{Financial support Non financial support}
1.Capital formation
1.Guidance 
Entrepreneurship and Startups
2.Investment
2.Acquiring license
3.Working capital
3.Idea generation
4.Ease of banking
4.Others
5.Others

Q.4) How is your business running at the initial stage?

Low medium high

Q.5) Are you aware of the recent schemes that are up for the startups?

Yes No

Q.6) Do you think that government is up to the mark in helping startups as per your awareness?

$\begin{array}{ll}\text { Strongly Agree } & \text { Agree } \\ \text { neutral } & \text { disagree }\end{array}$

Q.7) Can you see the positive outcome of the government from these startups as job creation and employment opportunities?

Yes No None

Q.8) At what range do you think will the GST bill plan of India help to grow startups?
$0-40 \%$
$40-80 \%$
$80-100 \%$

Q.9) Do you use any digital way of transaction in your business in support of government?

Yes

No
Q.10) Is your business creating jobs? Yes No

Q.11) Do you think colleges may bring out more startups?

Yes No None

Q.12) Do you think technology has played a major role in the success of business?

Yes

No

If yes in what way -

Digital payments

Online orders

Increasing productivity

M-business

others

Q.13) Do you support e business?

Yes No

Q.14) Has demonetization affected your business? if yes at what range?

$0-30 \% \quad 30-70 \% \quad 70-100 \%$ 